\title{
Properties of Pervious Concrete Containing Scrap Tyre Tubes
}

\author{
Koh Heng Boon ${ }^{1, *}$, David Yeoh ${ }^{1}$, and Norwati Jamaluddin ${ }^{1}$ \\ ${ }^{1}$ Department of Structural and Material Engineering, Faculty of Civil and Environmental Engineering, \\ Universiti Tun Hussein Onn Malaysia, 86400, Batu Pahat, Johor, Malaysia
}

\begin{abstract}
There is a huge quantity of waste tyre tubes generated every year due to the increasing of motorcycle user. Therefore, recycling of the waste tyre tubes is become mandatory. The aim of this research was to study the properties of pervious concrete containing scrap tyre tube (STT) rubber particles with percentages of $3 \%, 5 \%$ and $7 \%$ of the cement content. The properties studied are void content, compressive strength measured at 7,14 and 28 days, flexural strength and flow rate which were determined at 28 day. The experimental results showed that, there were increased in void content and flow rate of pervious concrete containing STT. Both compressive strength and flexural strength of pervious concrete containing STT showed a lower value compared to the control mix without STT. The reductions of the mechanical strengths are likely due to the increase of void content. Overall, pervious concrete which contains 7\% STT has shown an increment of mechanical strengths and flow rate compared to other STT pervious concrete. Nonetheless, the results indicate that there are potentials for use of STT in pervious concrete, especially for use in pervious concrete applications such as pavements, driveways and parking lots.
\end{abstract}

\section{Introduction}

With the ever increasing vehicles there is a growing need for recycling the waste tyre. The waste tyre generated annually in Malaysia was estimated approximately 57,391 tonnes and about $60 \%$ of the waste tyres are disposed via unknown routes [1]. Tyre landfilling is responsible for a serious ecological threat. Mainly waste tyres disposal areas contribute to the reduction of biodiversity also the tyres hold toxic and soluble components [2]. Waste tyre management and disposal is a major environmental concern in many countries. Waste tyre management is increasingly becoming a significant environmental, health, and aesthetic problem that is not easily solved. The use of waste tyres as a concrete additive is a possible disposal solution [3].

Pervious concrete can be other name as porous concrete or no fine concrete. It is different from conventional concrete in that it contains no fine aggregate. Combination the uniform coarse aggregate gradations and low water content such as water to cement ratios ranging from 0.25 to 0.35 make for a good concrete mixture with suitable void contents ranging from $11 \%$ to $35 \%[4,5]$. Pervious concrete characteristics differ from conventional

* Corresponding author: koh@uthm.edu.my 
concrete in several other ways. Compared to conventional concrete, pervious concrete has a lower compressive strength, higher permeability, and a lower unit weight, approximately $70 \%$ of conventional concrete [6].

Based on report published by American Concrete Institute [7], the use of pervious concrete for sustainable construction activities continues to rise due to its several environmental benefits. Most important among these benefits is the reduction of storm water runoff and recharging of groundwater when used as a paving material for parking lots, low volume pavements, and sidewalks. Pervious concretes have been found to be very effective in recharging groundwater and conserving water resources, making it an effective storm water management tool when used as a surface course in large exposed areas such as parking lots. Recently there has been considerable interest in using pervious concrete to mitigate the tyre-pavement interaction noise [8] in concrete pavements.

The use of waste tyres in normal weight concrete has been investigated since many years ago, but to date, research on the use of scrap tyre tubes (STT) in pervious concrete has not been found in Malaysia. Generally, concrete containing waste tyres gained lower compressive strength, but rubberized concrete has some desirable characteristics such as lower density, higher impact and toughness resistance, enhanced ductility and better sound insulation [9]. The aim of this research is to determine the effect of STT use in pervious concrete with regards to the void content, flow rate and mechanical properties. The mechanical properties that have been investigated are compressive strength and flexural strength.

\section{Experimental details}

\subsection{Materials}

Constituent materials for pervious concrete mixes included Portland composite cement meeting MS EN 197-1:2007 [10] requirements, crushed granite aggregate with a nominal size of $10 \mathrm{~mm}$, tyre tube-rubber particles processed from scrap tyre tubes (STT) with a nominal size of $6 \mathrm{~mm}$ and superplasticizer. STT were collected from the motorcycle workshops in Parit Raja. STT were washed to remove the dust and grease. STT were cut into small irregular shape particles by using plastic granulator machine. The STT and tyre tube-rubber particles are shown in Fig. 1 and Fig. 2, respectively. Tyre tube particles were not pretreated before incorporation into the pervious concrete mixture.

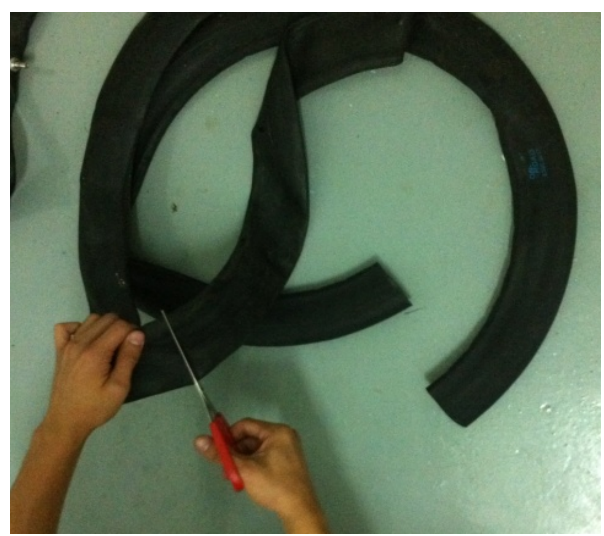

Fig. 1. Scrap tyre tube.

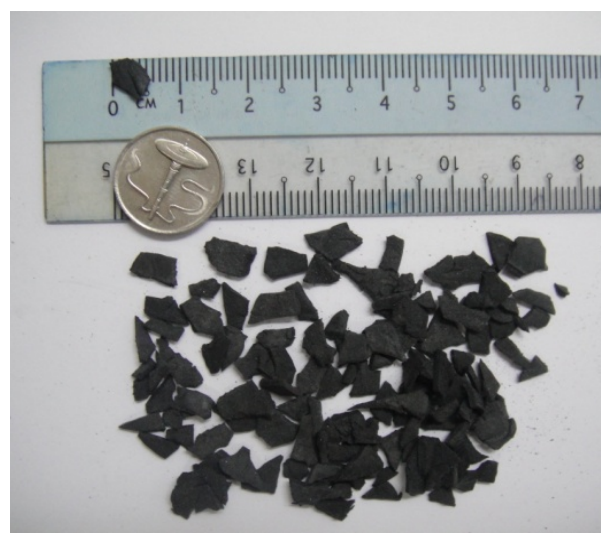

Fig. 2. Processed tyre tube-rubber particles. 


\subsection{Mix design}

Four pervious concrete mixes, as shown in Table 1 were prepared. Since, there is no existing standard method of designing concrete mixes incorporating STT, the method of mix design proposed by Bhutta et al. [11] was employed to design a pervious concrete mix without STT. The mix was designed to have a 28-day target compressive strength of 10 MPa. STT particles were used as the additive with percentages by weight of $3 \%, 5 \%$ and $7 \%$ of the cement content. Superplasticiser of 1 litre $100 \mathrm{~kg}$ cement was used to increase the workability of the low water cement ratio pervious concrete mixtures.

Table 1. Pervious concrete mixture proportions

\begin{tabular}{|c|c|c|c|c|c|c|}
\hline $\begin{array}{c}\text { Mix } \\
\text { ID }\end{array}$ & $\begin{array}{c}\text { Cement } \\
\left(\mathbf{k g} / \mathbf{m}^{\mathbf{3}}\right)\end{array}$ & $\begin{array}{c}\text { Coarse } \\
\text { Aggregates } \\
\left(\mathbf{k g} / \mathbf{m}^{\mathbf{3}}\right)\end{array}$ & $\begin{array}{c}\text { Tyre Tube- } \\
\text { Rubber } \\
\text { Particles } \\
\left(\mathbf{k g} / \mathbf{m}^{\mathbf{3}}\right)\end{array}$ & $\begin{array}{c}\text { Water } \\
(\mathbf{l i t r e})\end{array}$ & $\begin{array}{c}\text { Superplasticiser } \\
\text { (litre) }\end{array}$ & Remark \\
\hline M0 & 350 & 1430 & 0 & 105 & 3.5 & $\begin{array}{c}\text { Control mix } \\
-0 \% \text { STT }\end{array}$ \\
\hline M1 & 350 & 1430 & 10.5 & 105 & 3.5 & $3 \%$ STT \\
\hline M2 & 350 & 1430 & 17.5 & 105 & 3.5 & $5 \%$ STT \\
\hline M3 & 350 & 1430 & 24.5 & 105 & 3.5 & $7 \%$ STT \\
\hline
\end{tabular}

\subsection{Specimens and tests}

Concrete cubes of $100 \times 100 \times 100 \mathrm{~mm}$ were used to evaluate the compressive strength and void content. Rectangular prisms size $100 \times 100 \times 500 \mathrm{~mm}$ length was used for evaluating flexural strength. Meanwhile, two types of panel size $300 \times 300 \times 25 \mathrm{~mm}$ thick and $300 \mathrm{x}$ $300 \times 25 \mathrm{~mm}$ thick were used for the flow test. All specimens were cured under the water until the testing age. The number of specimens used in the tests and the distribution is tabulated in Table 2 .

Table 2. Number of specimens

\begin{tabular}{|c|c|c|c|c|}
\hline \multirow{2}{*}{ Specimen } & Test & \multicolumn{3}{|c|}{ Number of specimens } \\
\cline { 3 - 5 } & & $\mathbf{7 - d a y}$ & $\mathbf{1 4 - d a y}$ & $\mathbf{2 8 - d a y}$ \\
\hline $100 \times 100 \times 100 \mathrm{~mm}$ cube & Compressive Strength & 3 & 3 & 3 \\
\hline $100 \times 100 \times 100 \mathrm{~mm}$ cube & Void Content & - & - & 3 \\
\hline $100 \times 100 \times 500 \mathrm{~mm}$ prism & Flexural Strength & - & - & 3 \\
\hline $\begin{array}{c}300 \times 300 \times 25 \mathrm{~mm} \text { thick } \\
\text { panel }\end{array}$ & Flow Rate & - & - & 2 \\
\hline $\begin{array}{c}300 \times 300 \times 50 \mathrm{~mm} \text { thick } \\
\text { panel }\end{array}$ & Flow Rate & - & - & 2 \\
\hline
\end{tabular}

Compressive strength test was conducted based on BS EN 12390-3: 2009 [12]. Three cubes were tested for each age. Concrete cubes used for void content are the same cubes used for the 28 day compressive strength test. Void content test (Fig. 3) was carried out at 28 day accordance to BS EN 12390-7: 2009 [13]. Void content of pervious concrete is defined as the percentage of the total volume of void to the total volume of specimen. It was calculated based on the following equation:

$$
\text { Void } \text { content }(\%)=1-\left[\frac{(W 2-W 1)}{v p}\right] x 100
$$


where;

W1 is the weight of specimen submerged under water $(\mathrm{kg})$

$\mathrm{W} 2$ is the weight of specimen at a saturated surface dry condition $(\mathrm{kg})$

$\mathrm{v}$ is the volume of specimen $\left(\mathrm{m}^{3}\right)$

$\rho$ is the density of water in $\left(\mathrm{kg} / \mathrm{m}^{3}\right)$

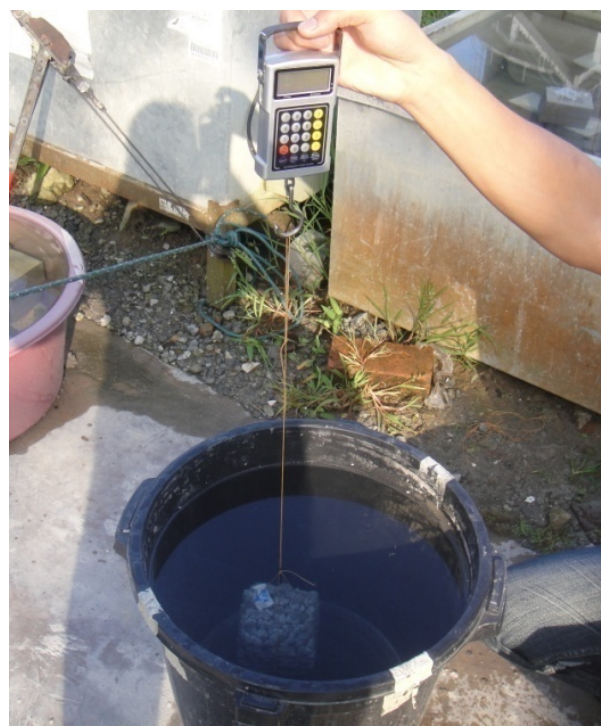

Fig. 3. Void content test.

Flexural strength test was carried out based on BS EN 12390-5: 2009 [14]. Three prisms were tested for the flexural strength at 28 days. Four-point flexural strength test is shown in Fig. $4.300 \mathrm{~mm}$ square pervious concrete panels were tested for the vertical and horizontal flow rate at 28 days. Since, there is no existing standard method of testing flow rate for pervious concrete, two apparatus were designed for the test. Fig. 5 and Fig 6. show the schematic diagram for the vertical flow test and apparatus for the horizontal flow test, respectively.

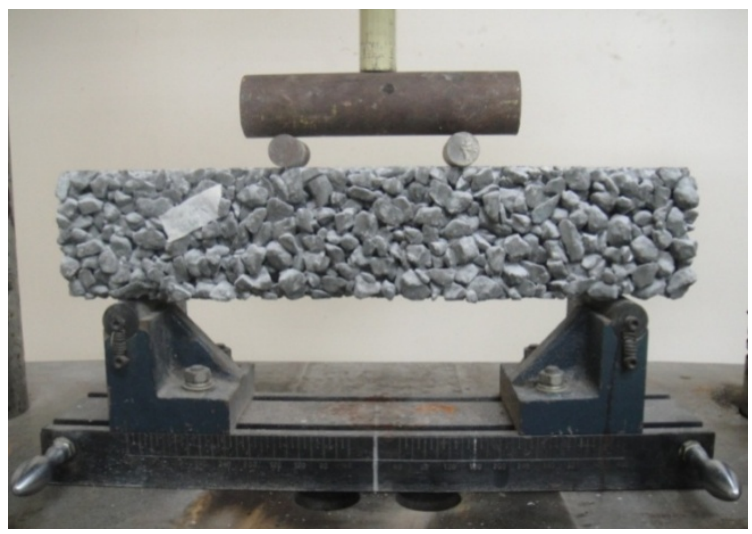

Fig. 4. Four-point flexural strength test. 


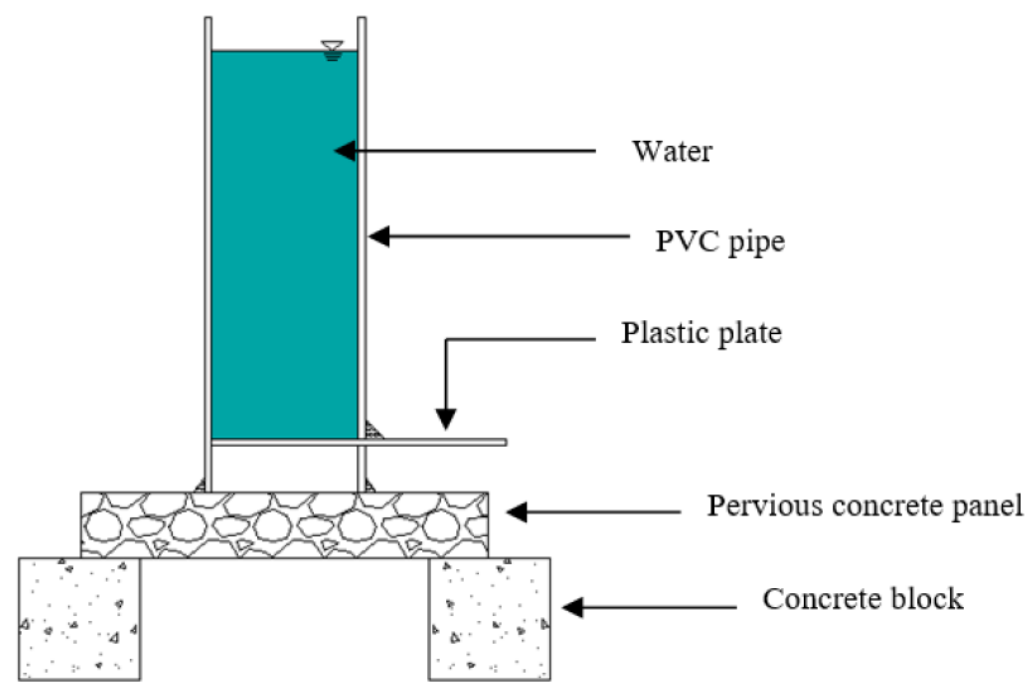

Fig. 5. Schematic diagram of horizontal flow rate test.

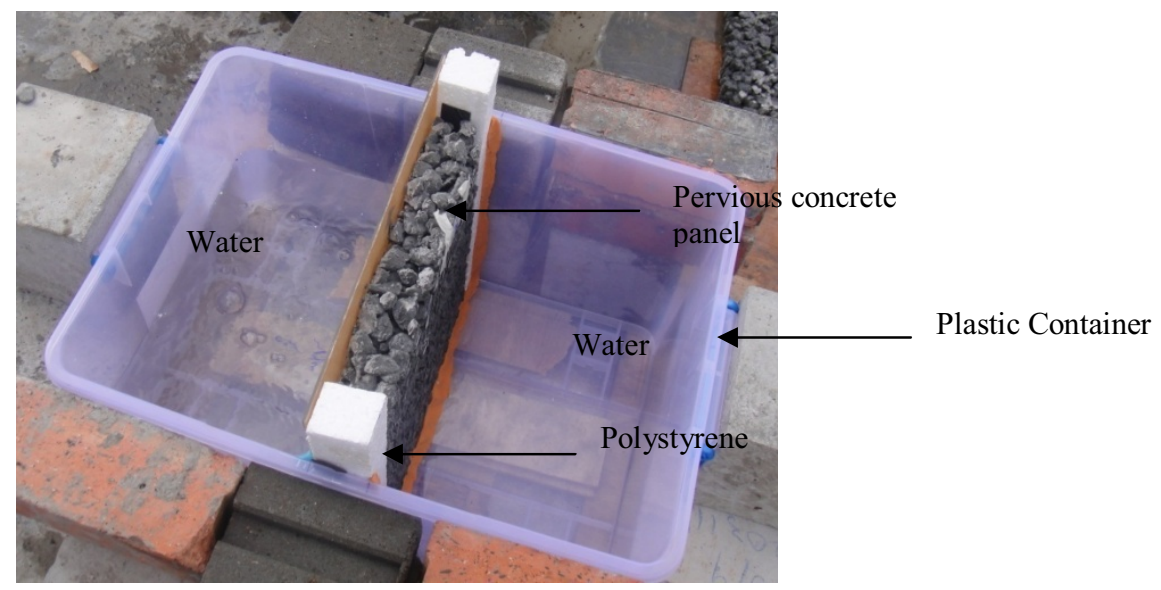

Fig. 6. Apparatus for the horizontal flow rate test.

\section{Results and discussions}

\subsection{Void content}

The results of void content are shown in Fig. 7. Results showed that pervious concrete containing STT rubber particles achieved higher void content compared to the control specimen. The control specimen (M0) without STT achieved the lowest void content of $28 \%$. The results obtained in this study are similar to the findings of Yukari [15] that void content is slightly higher for self-compacting no fines concrete containing small particles additives. However, the effect of increasing STT particles as shown in the figure, which indicates that there was a reduction of void content. This can be seen from the void content of M1 specimen ( $3 \%$ STT), which recorded the highest value of $31 \%$ has reduced gradually to $30 \%$ and $29 \%$ for M2 (5\% STT) and M3 (7\% STT) specimens, respectively. 


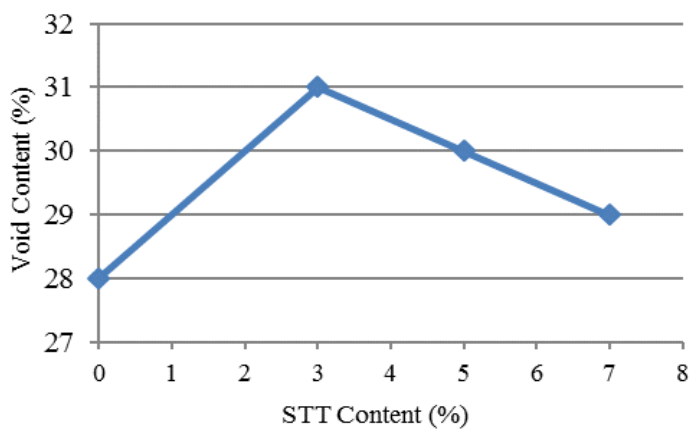

Fig. 7. Void content of pervious concrete.

\subsection{Compressive strength and flexural strength}

The compressive strength development of $100 \mathrm{~mm}$ cubes of M0-M3 mixes are shown in Fig. 8. In order to compare the relative gain of strength at different ages, the compressive strength of the mixes is also presented in Fig. 9. Results showed that all STT mixes gained lower compressive strength for all ages. Among all the pervious concrete containing STT, the compressive strength for M3 is slightly higher than M1 and M2. At 28 day, control specimens (M0) achieved the highest compressive strength of $11.3 \mathrm{MPa}$ followed by M3, which gained 7.6 MPa, M2 achieved 6.35 MPa and M1 achieved the lowest compressive strength with $5.8 \mathrm{MPa}$. The graphical presentation of the 28 days compressive strength is given in Fig. 10. The reduction of compressive strength for pervious concrete containing STT may be due to the increment of void content and the STT particles are not distributed uniformly in the concrete.

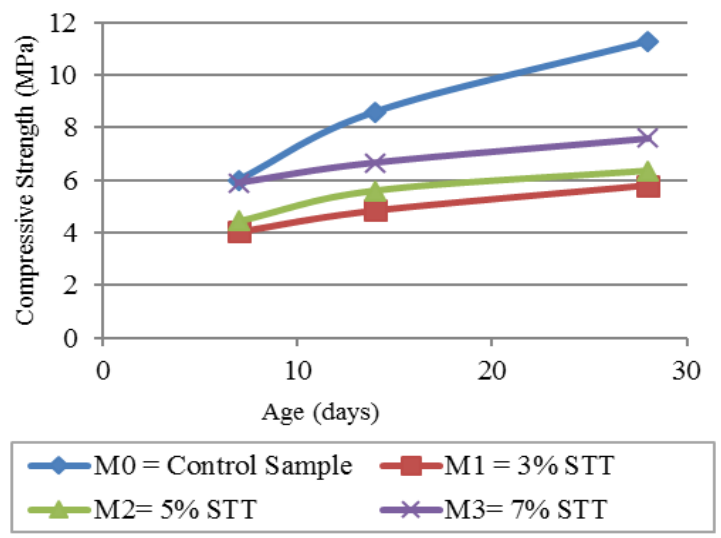

Fig. 8. Compressive strength development of pervious concrete.

Fig. 11 shows the plot of 28 day compressive strength of pervious concrete against void content of this study together with the findings by Tennis et al. [4], Bhutta et al. [11], Schaefer et al. [5] and Ireen Azfar, [16]. Based on the data shown in Fig. 11, the compressive strength of pervious concrete is inversely proportional to the void content.

Results of the 28 day flexural strength are shown in Fig. 12. It can be seen that, flexural strength for all pervious concrete containing STT particles is lower compared to the control specimens. Based on the plot, there is no specific trend in the relationship between the proportion of STT added in pervious concrete and flexural strength. The ratio between 
compressive strength and flexural strength is presented in Table 3. M1 and M3 specimens have shown a higher value of the ratio between the flexural strength and compressive strength. Pervious concrete containing 7\% STT particles gained 3.9\% higher than the control specimen (M0). The results obtained here show that, the use of STT more than 7\% has the tendency to improve flexural strength of pervious concrete.

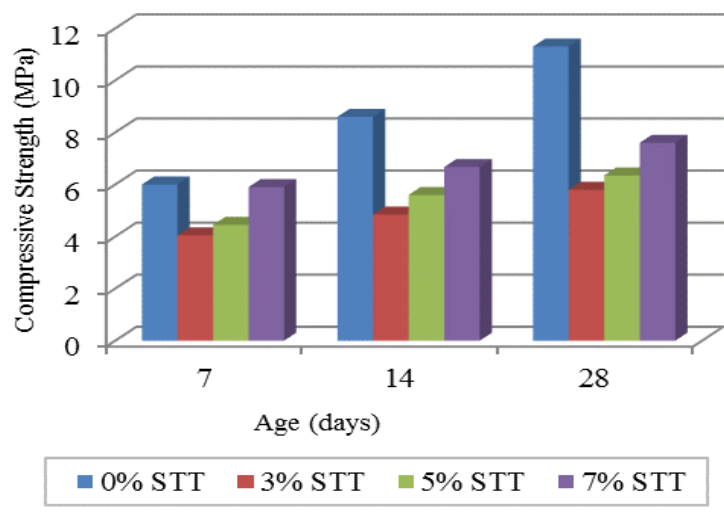

Fig. 9. Compressive strength of pervious concrete.

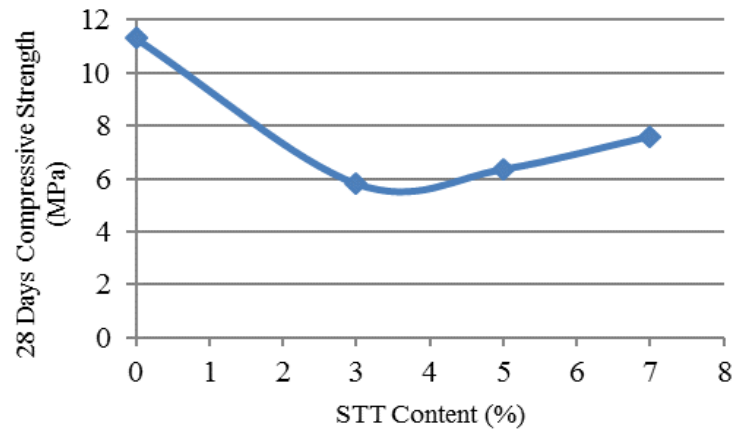

Fig. 10. 28 days compressive strength of pervious concrete.

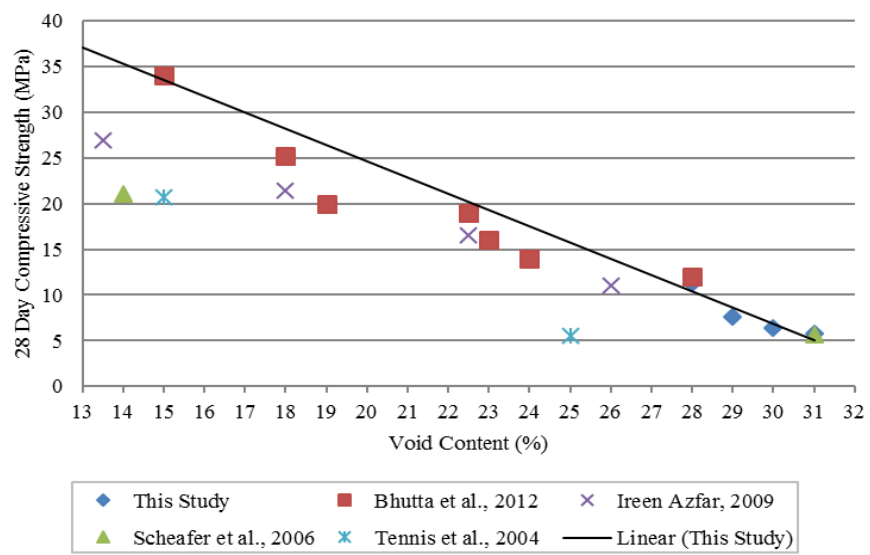

Fig. 11. 28 day compressive strength against void content. 


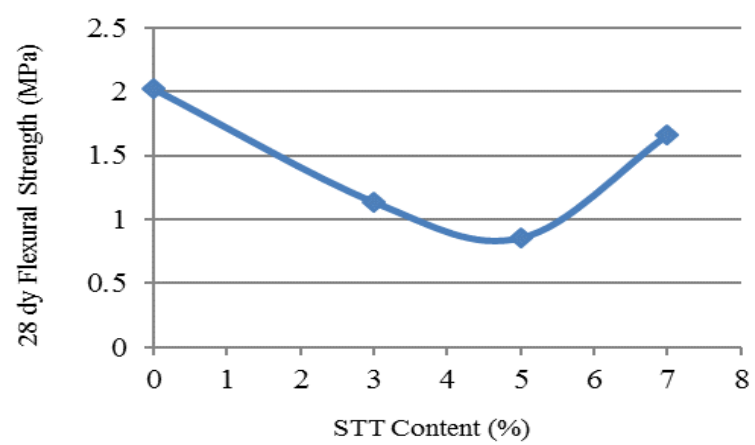

Fig. 12. Flexural strength of pervious concrete.

Table 3. Ratio of compressive strength / flexural strength

\begin{tabular}{|c|c|c|c|}
\hline $\begin{array}{c}\text { Mix } \\
\text { ID }\end{array}$ & $\begin{array}{c}\text { 28 day } \\
\text { compressive } \\
\text { strength (MPa) }\end{array}$ & $\begin{array}{c}\text { 28 day flexural } \\
\text { strength } \\
\text { (MPa) }\end{array}$ & $\begin{array}{c}\text { Percentage of } \\
\text { flexural strength/ } \\
\text { compressive strength (\%) }\end{array}$ \\
\hline M0 & 11.3 & 2.02 & 17.9 \\
\hline M1 & 5.8 & 1.13 & 19.5 \\
\hline M2 & 6.35 & 0.85 & 13.4 \\
\hline M3 & 7.6 & 1.66 & 21.8 \\
\hline
\end{tabular}

\subsection{Flow rate}

Fig. 13 shows the vertical flow rate of the pervious concrete. Time to achieve the same water level in horizontal flow test is shown in Fig. 14. As expected, pervious concrete with higher void content achieved higher flow rate. The thicker panel achieved a lower vertical flow rate and horizontal flow. Vertical flow rate of 97.6 to $139.8 \mathrm{~L} / \mathrm{m}^{2} / \mathrm{s}$ was achieved by the thin panels. Meanwhile, the thicker panels achieved a vertical flow rate of 92.4 to 126.2 $\mathrm{L} / \mathrm{m}^{2} / \mathrm{s}$. For the horizontal flow, 22 litre water was used in the test. The time ranging from 3.0 to 5.9 seconds was recorded for achieving the same water level.

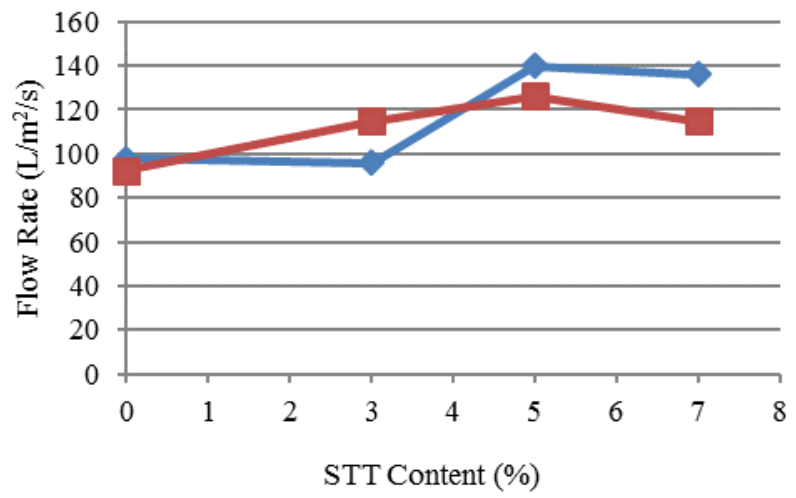

\section{$\longrightarrow$ Slab $25 \mathrm{~mm}$ Thk. $\quad$ Slab 50mm Thk.}

Fig. 13. Vertical flow rate. 


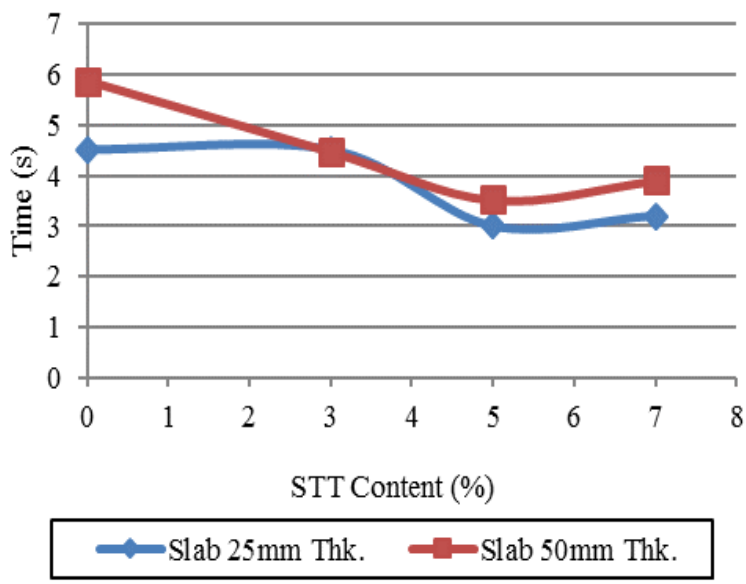

Fig. 14. Time achieved for horizontal flow.

\section{Conclusion}

Inclusion of scrap tyre tube rubber particles led to increment in void content and reductions in strengths of pervious concrete. However, pervious concrete with coarse rubber particles exhibits an acceptable compressive strength of more than $5 \mathrm{MPa}$. There is no distinct relationship could be established between the properties (flexural strength and flow rate) and proportion of rubber particles in pervious concrete mixes.

This study has focused on the void content, mechanical strengths and flow rate of pervious concrete containing small quantity of scrap tyres tube rubber particles. The results obtained in this study showing that there are potentials for use of scrap tyre tube rubber particles in pervious concrete. Pervious concrete which contains 7\% STT has achieved higher mechanical strengths with better flow rate compared to other STT pervious concrete. However, there is a need for future studies to investigate the properties of pervious concrete with high volume scrap tyres tube rubber particles, and the durability of pervious concrete.

The experiments were performed in the Laboratory of Materials Engineering at Universiti Tun Hussein Onn Malaysia. The pervious concrete samples were prepared by Mr. Ch'ng Han Leong with the help of laboratory technicians. The authors wish to express the acknowledgements to their help.

\section{References}

[1] S.K. Thiruvangodan, Waste tyre management in Malaysia, PhD Thesis, Universiti Putra Malaysia, Malaysia, (2006)

[2] K. Day, K. Holtze, J. Metcalfe, C. Bishop, B. Dutka, Toxicity of leachate from automobile tyres to aquatic biota, Chemosphere, 27, 665-75, (1993)

[3] A.R. Khaloo, M. Dehestania, P. Rahmatabadi, Mechanical properties of concrete containing a high volume of tire-rubber particles, Waste Management, 28, 2472-2482, (2008)

[4] P.D. Tennis, M.L. Leming, D.J. Akers, Pervious concrete pavements, EB302.02, Portland Cement Association, Skokie, Illinois, and National Ready Mixed Concrete Association: Silver Spring, Maryland, (2004) 
[5] V.R. Schaefer, K. Wang, M.T. Suleimam, J. Kevern, Mix design development for pervious concrete in cold weather climates, Center for Transportation Research and Education, Iowa State University, (2006)

[6] A.M. Mulligan, Attainable compressive strength of pervious concrete paving systems, MSc Thesis, University of Central Florida Orlando, (2005)

[7] ACI 522R-10, Pervious concrete, American Concrete Institute Committee, (2010)

[8] O. Deo, N. Neithalath, Compressive behavior of pervious concretes and a quantification of the influence of random pore structure features, Materials Science and Engineering A. 528, 402-212, (2010)

[9] R. Siddique, T.R. Naik, Properties of concrete containing scrap-tire rubber - An overview, Waste Management, 24, 563-569, (2004)

[10]MS EN 197-1, Cement - Composition, specifications and conformity criteria for common cements, Department of Standards Malaysia, Malaysia, (2007)

[11] M.A.R. Bhutta, K. Tsuruta, J. Mirza, Evaluation of high-performance porous concrete properties, Construction and Building Materials, 31, pp. 67-73, (2012)

[12]BS EN 12390-3, Testing hardened concrete. Compressive strength of test specimens, British Standards Institution, London, (2009)

[13]BS EN 12390-7, Testing hardened concrete. Density of hardened concrete, British Standards Institution, London, (2009)

[14]BS EN 12390-5, Testing hardened concrete. Flexural strength test specimens, British Standards Institution, London, (2009)

[15]B.E.M.E. Yukari Aoki, Development of pervious concrete, Master Thesis, University of Technology, Sydney, (2009)

[16]B.S. Ireen Azfar, Evaluation of pervious concrete as a best management practice for stormwater in Edwards Aquifer Region, Master Thesis, University of Texas, San Antonio, United States, (2009) 